\title{
Species diversity and litter dynamics in secondary mixed deciduous forest, Thung Salaeng Lung National Park, Northern, Thailand
}

\author{
Chattanong Podong ${ }^{1} \bowtie$, Roongreang Poolsiri ${ }^{2}$, Klaus Katzensteiner $^{3}$, \\ Pattra Pengthamkeerati ${ }^{4}$, Piyapong Thongdeenok ${ }^{1}$ \\ ${ }^{1}$ KasetsartUniversity, Faculty of Forestry, Department of Conservation, Chatuchak, Bangkok, Thailand 10900, \\ e-mail: chattanong@hotmail.com \\ ${ }^{2}$ Kasetsart University, Faculty of Forestry, Department of Sivilculture, Chatuchak, Bangkok, Thailand 10900 \\ ${ }^{3}$ Institute of Forest Ecology, Department of Forest and Soil science, University of Natural Resource and Applied Life \\ Science, Gregor Mendel Straße 33, A-1190 Wien, Vienna, Austria \\ ${ }^{4}$ Kasetsart University, Faculty of Science, Department of Environmental Science, Chatuchak, Bangkok, Thailand 10900
}

\section{Abstract}

This study present species composition and potential of litter on carbon and nitrogen return in secondary mixed deciduous forest after shifting cultivation. The dominant species of trees were Haldina cordifolia, Albizia odoratissima and Lagerstroemia duperreana. The Important Value Index (IVI) values of trees were 132.91, 17.78 and 14.22, respectively. The pattern for the decomposition coefficients $(k)$ was highest in the wet period (May-September) and lowest in the dry period (October-April). The carbon and nitrogen return patterns increased in the dry period (October-April) and decreased in the wet period (May-September). Carbon and nitrogen loss in the decomposing litter continually decreased during the decomposition process from the initial levels, with a final relatively rapid release in the wet period. Results from this study was understanding of community composition, litterfall production and litter decomposition for understanding potential of secondary mixed deciduous forest for balancing carbon for mitigating greenhouse gas effect in the local area.

\section{KeY WORDS}

species composition, litter, carbon, nitrogen, secondary mixed deciduous forest, shifting cultivation

\section{INTRODUCTION}

Shifting cultivation has been practiced all over the world and two-thirds of the world's secondary forest area in 1980 was shifting cultivation fallow (Lanly 1982). The currently degraded forest in upland northern
Thailand is largely the result of shifting cultivation and it was logged forest converted to agricultural land by shifting cultivators. In general, the main shifting cultivation in mountainous area northern Thailand is upland rice, which is cultivated together with numerous other crops, such as cotton, sorghum, pepper, squash, yam, 
cucumber, millet, sesame, red pepper, and various herbs and spices (Fugushima et al. 2007). The shifting cultivation in lower northern Thailand is upland area so; the main shifting cultivation is economic cultivation such as maize, cassava, cotton, chili and fruit.

Studies of secondary forest regeneration in Southeast Asia have been made in Peninsular Malaysia (Symington 1933; Wyatt-Smith 1955; Kochummen 1966; Kochummen, Ng 1977), Thailand (Kunstadter et al. 1978), the Philippines (Kellman 1969) and East Kalimantan (Kartawinata 1977; Kartawinata et al. 1980; Sukardjo 1990; Riswan, Kartawinata 1991). Some of these studies dealt with secondary succession after agricultural land use while others used experimental manipulation to compare secondary forest recovery under a range of conditions.

In Thailand, previous studies have recognized that differences in shifting farming practices of various ethnic groups have resulted in differences in the secondary forest (Fugushima et al. 2007) in mountainous area northern Thailand. The previous reporting studied secondary forest in fallow fields after shifting cultivation by the Karen, Hmong, and Lisu groups and reported relatively rapid forest recovery after shifting cultivation by the Karen compared to the other groups (Kanjunt, Oberhauser 1994) and an experimental shifting cultivation in which primary forest was burned for upland farming in northeastern Thailand (Kyuma, Pairintra 1983; Boonyanuphap 2007).

The litter which is produced by a forest has different amount and different composition based on the structure and the species diversity of the plant which compiles it (Triadiati et al. 2011). The litter on the forest floor acts as input-output system of nutrient and the rates at which forest litter falls and subsequently, decomposes contribute to the regulation of nutrient cycling and primary productivity and to the maintenance if soil fertility in forest ecosystem. Therefore, it is critical to understand the amount and pattern of litterfall in these forest ecosystems (Berg 2000; Lobret et al. 2001; Ranger et al. 2003; Wang et al. 2008). Carbon budget is carbon balance between input process and output process in area, and litter is main material for input process. Litterfall and litter decomposition and subsequent nutrient release represent major biological pathways for element transfer from vegetation to soils, and play an important role in regulating nutrient cycling, and in maintaining soil fertility in forest and agro-ecosystems (Yang et al. 2003). In forest and agro ecosystem litter acts as an input-output system of nutrients and the rates at which forest litter falls contribute to the regulation of nutrient cycling, fertility sustenance and primary productivity in forest and tree-based ecosystems (Berg 2000; Ranger et al. 2003).

Despite many studies carried out on litterfall and decomposition dynamics, in both tropical and temperate forests and agroforests (Berg 2000; Ranger et al. 2003; Martius et al. 2004; Isaac et al. 2005). Litter fall and decomposition can be impacted both by the structural and floristic changes that occur over secondary succession (Ostertag et al. 2008). Past research has demonstrated that structural variables such as canopy closure, basal area, and stem density generally recover much faster than pre-disturbance species composition (Finegan 1996; Guariguata, Ostertag 2001; Chazdon 2003). More commonly, studies compare secondary forest of a single age to plantations or to primary forest (Cuevas et al. 1991; Lugo 1992; Li et al. 2005) or compare data worldwide across forests of different ages (Brown, Lugo 1990).

The present study was carried out to litter dynamics in relation to carbon and nitrogen return to secondary mixed deciduous forest, Thailand.

\section{MAterial AND MEthodS}

\section{Study area}

The study site was located in lower northern, Thailand at an altitude of approximately $700-860 \mathrm{~m}$ above sea level. The study area covered forest in the Thung Salang Luang National Park and some adjacent Para rubber tree plantation. The geological formation of the study area is composed of sedimentary rock and metamorphic rock (Royal Forest Department 1962). The climate is tropical and sub-tropical with three distinct seasons-winter, summer and monsoon. While the mean temperature is $22^{\circ} \mathrm{C}$, March to June are the hottest months with a mean maximum temperature of $29^{\circ} \mathrm{C}$, and November to February are the coldest months with a mean minimum temperature of $17^{\circ} \mathrm{C}$. The maximum rainfall occurs during the monsoon season from May to October with a annual rainfall of 1,300-1,700 $\mathrm{mm}$. The study was undertaken from April 2010 to March 2011. 


\section{Species composition}

Tree species composition data was collected from permanent 4 plots in $50 \times 50 \mathrm{~m}$ quadrate that divided into 25 sub plots of $10 \times 10 \mathrm{~m}$. A vegetation census was used to collect data on forest structure and species composition. All trees in these plots were recorded all trees $\mathrm{DBH}>4.5 \mathrm{~cm}$ in each plot of $10 \times 10 \mathrm{~m}$. All trees was calculated The importance value index (IVI) of each sample plot was determined as follows: IVI $=$ Relative density $(\%)+$ Relative frequency $(\%)+$ Relative dominance $(\%)$.

\section{Litterfall collection}

Litterfall was collected monthly for one year at $1.30 \mathrm{~m}$ above ground level using nine litter traps $(1 \times 1 \mathrm{~m})$ set up in each plot of $50 \times 50 \mathrm{~m}$, with four plots providing a total of 36. All accumulated litter in each trap was collected every month during the one-year period, and afterwards sorted into leaves, twigs, barks, reproductive, and other fractions; each fraction was oven dried at $80^{\circ} \mathrm{C}$ for $24-48 \mathrm{hr}$ and then weighed for analysis of the total carbon and total nitrogen content. Climatic variables (rainfall and maximum and minimum temperature) were also monitored on site during the study period, using appropriate measuring equipment.

\section{Litter decomposition}

Litter decomposition data were collected from a mix of leaves sampled from the five dominant species. The weight was calculated by the important value index (IVI) ratio using a $30 \mathrm{~g}$ subsample from each leaf sample. Each subsample was placed in a vinyl litter bag $(30 \times 30 \mathrm{~cm})$ with 36 bags per plot of $50 \times 50 \mathrm{~m}$, so the four plots had a total of 144 bags. Three bags were retrieved randomly from the field at one-month intervals for 1 year. The contents were emptied and extraneous material, such as soil, visible animals and fine roots were removed. The remaining sample was oven dried at $80^{\circ} \mathrm{C}$ for $24-48 \mathrm{hr}$ to constant weight to determine the final weight of the sample and for analysis of the total carbon and total nitrogen content. A single exponential equation, according to an exponential decay model (Olsen 1963), was used to calculate the decomposition constant $(k)$ and the rates of loss of carbon and nitrogen using equation (1):

$$
\ln \left(\mathrm{X}_{t} / \mathrm{X}_{0}\right)=-k \mathrm{t}
$$

where

$\mathrm{X}_{0}$ - the original weight of litter,

$\mathrm{X}_{t}$ - the final weight of litter,

$k$ - decomposition constant,

$\mathrm{t}$ - the time,

ln - natural logarithm.

\section{Carbon and nitrogen analysis}

The carbon and nitrogen analysis of plant litter was carried out at the Department of Silviculture, Faculty of Forestry, Kasetsart University using a CHN Analyzer (PerkinElmer 2400 series II CHNS/O).

\section{Results}

\section{Species composition}

The results showed that number of species of all plots in present study was nearly other forest (tab. 1 and 2). It is probable that moisture content of soils in MEF and DEF in this comparison is higher than other forests in other site.

Tab. 1. Number of species, tree density of some forest types in Thailand, only trees with $\mathrm{DBH} \geq 4.5 \mathrm{~cm}$ were included

\begin{tabular}{|l|l|c|c|l|}
\hline Forest & \multicolumn{1}{|c|}{ Area } & $\begin{array}{c}\text { No. of } \\
\text { species } \\
\text { /ha }\end{array}$ & $\begin{array}{c}\text { Tree } \\
\text { density } \\
\text { /ha }\end{array}$ & \multicolumn{1}{|c|}{ Source } \\
\hline SMDF & $\begin{array}{l}\text { Thung Salaeng } \\
\text { Luang National } \\
\text { Park }\end{array}$ & 35 & 2,025 & Present study \\
\hline MDF & $\begin{array}{l}\text { Huai Kha Khaeng } \\
\text { Wildlife Sactuary }\end{array}$ & 21 & 780 & $\begin{array}{l}\text { Srikanha } \\
\text { and Gajaseni } \\
1999\end{array}$ \\
\hline MDF & $\begin{array}{l}\text { Khao Kaset } \\
\text { Forest area }\end{array}$ & 33 & 959 & $\begin{array}{l}\text { Khophai } \\
2006\end{array}$ \\
\hline MDF & $\begin{array}{l}\text { Khun Korn } \\
\text { Waterfall } \\
\text { Forest park }\end{array}$ & 62 & 358 & Nukool 2002 \\
\hline DDF & $\begin{array}{l}\text { Huai Kha Khaeng } \\
\text { Wildlife Sactuary }\end{array}$ & 14 & 720 & $\begin{array}{l}\text { Srikanha } \\
\text { and Gajaseni } \\
1999\end{array}$ \\
\hline SDDF & $\begin{array}{l}\text { Kalasin Forest } \\
\text { area }\end{array}$ & 22 & 1,444 & $\begin{array}{l}\text { Kanzaki } \\
1991\end{array}$ \\
\hline MEF & $\begin{array}{l}\text { Khao Khitchakut } \\
\text { National Park }\end{array}$ & 135 & 1,510 & $\begin{array}{l}\text { Glumphabutr } \\
\text { et al 2006 }\end{array}$ \\
\hline DEF & $\begin{array}{l}\text { Khao Soi Dao } \\
\text { Wildlife Sanctury }\end{array}$ & 138 & 1,355 & $\begin{array}{l}\text { Glumphabutr } \\
\text { et al 2006 }\end{array}$ \\
\hline
\end{tabular}


Tab. 2. Relative density, relative frequency, relative dominance and important value index of trees $(\mathrm{DBH} \geq 4.5)$ in SMDF plot

\begin{tabular}{|l|c|c|c|c|}
\hline $\begin{array}{c}\text { Tree group } \\
\text { Scientific name }\end{array}$ & $\begin{array}{c}\% \\
\text { Relative } \\
\text { density }\end{array}$ & $\begin{array}{c}\% \\
\text { Relative } \\
\text { frequency }\end{array}$ & $\begin{array}{c}\% \\
\text { Relative } \\
\text { dominance }\end{array}$ & IVI \\
\hline $\begin{array}{l}\text { Haldina } \\
\text { cordifolia }\end{array}$ & 49.34 & 78.62 & 4.94 & 132.91 \\
\hline $\begin{array}{l}\text { Albizia } \\
\text { odoratissima }\end{array}$ & 5.58 & 7.27 & 4.94 & 17.78 \\
\hline $\begin{array}{l}\text { Lagerstroemia } \\
\text { duperreana }\end{array}$ & 6.89 & 2.39 & 4.94 & 14.22 \\
\hline $\begin{array}{l}\text { Fermandoa } \\
\text { adenophylla }\end{array}$ & 6.60 & 2.35 & 4.94 & 13.89 \\
\hline $\begin{array}{l}\text { Croton } \\
\text { roxburghii }\end{array}$ & 5.00 & 1.15 & 4.94 & 11.08 \\
\hline $\begin{array}{l}\text { Harrisonia } \\
\text { perforata }\end{array}$ & 3.35 & 2.62 & 4.94 & 10.91 \\
\hline $\begin{array}{l}\text { Cratoxylum } \\
\text { formosum }\end{array}$ & 3.44 & 1.39 & 4.94 & 9.77 \\
\hline $\begin{array}{l}\text { Dalbergia } \\
\text { foliacea }\end{array}$ & 3.49 & 1.13 & 4.94 & 9.57 \\
\hline Xylia xylocarpa & 2.52 & 1.06 & 4.94 & 8.52 \\
\hline $\begin{array}{l}\text { Antidesma } \\
\text { sootepense }\end{array}$ & 3.15 & 0.40 & 4.94 & 8.50 \\
\hline
\end{tabular}

\section{Litterfall production}

Monthly patterns of litterfall production were similar among the four sites, with a peak during the dry period and dips during the wet period (tab. 3) (fig. 1). Annual litterfall production in the secondary mixed deciduous forest was $416.40 \pm 19.35 \mathrm{~g} / \mathrm{m}^{2} /$ year.

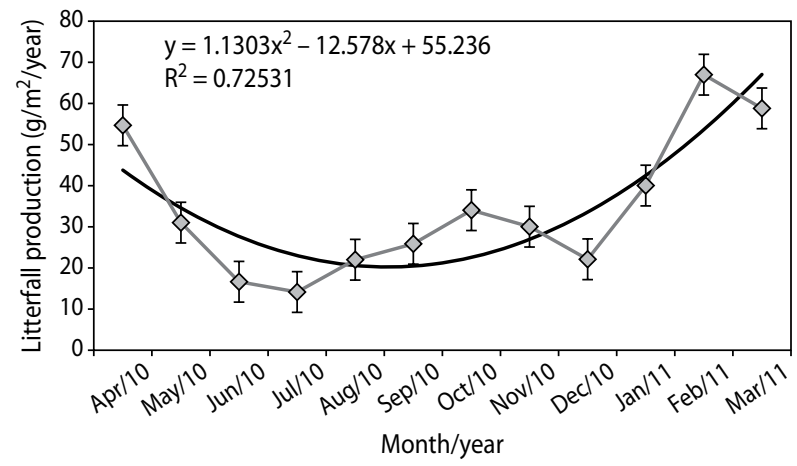

Fig. 1. Monthly variation in litterfall production $\left(\mathrm{g} / \mathrm{m}^{2} / \mathrm{year}\right)$ of secondary mixed deciduous forest (SMDF) from April 2010 to March 2011
Tab. 3. Amount of litterfall ( $\mathrm{g} / \mathrm{m}^{2} /$ year) collected over 1 year during two periods (wet and dry) under secondary mixed deciduous forest. The contribution of each fraction of litterfall to total litterfall production is also reported and Data are mean $\pm \mathrm{SE}$ and the data was test significant diffences between wet and dry periods

\begin{tabular}{|c|c|}
\hline Litterfall fraction/periods & $\begin{array}{l}\text { Secondary mixed deciduous } \\
\text { forest }\end{array}$ \\
\hline \multicolumn{2}{|c|}{ Leaf } \\
\hline Wet period & $54.13^{a} \pm 3.27$ \\
\hline Dry period & $191.72^{b} \pm 13.42$ \\
\hline Total & $245.85 \pm 79.44$ \\
\hline \multicolumn{2}{|c|}{ Twigs } \\
\hline Wet period & $43.27^{\mathrm{a}} \pm 4.39$ \\
\hline Dry period & $90.42^{b} \pm 4.74$ \\
\hline Total & $133.69 \pm 33.35$ \\
\hline \multicolumn{2}{|c|}{ Bark } \\
\hline Wet period & $2.46^{\mathrm{a}} \pm 0.57$ \\
\hline Dry period & $2.70^{\mathrm{a}} \pm 0.54$ \\
\hline Total & $5.15 \pm 0.17$ \\
\hline \multicolumn{2}{|c|}{ Reproductive } \\
\hline Wet period & $8.33^{a} \pm 0.93$ \\
\hline Dry period & $12.28^{\mathrm{b}} \pm 2.76$ \\
\hline Total & $20.62 \pm 2.79$ \\
\hline \multicolumn{2}{|c|}{ Other fraction } \\
\hline Wet period & $4.29^{a} \pm 0.82$ \\
\hline Dry period & $6.81^{\mathrm{a}} \pm 1.97$ \\
\hline Total & $11.09 \pm 1.78$ \\
\hline \multicolumn{2}{|c|}{ Litterfall } \\
\hline Wet period & $112.47^{\mathrm{a}} \pm 24.31$ \\
\hline Dry period & $303.97^{\mathrm{a}} \pm 81.64$ \\
\hline Total & $416.40^{\mathrm{a}} \pm 19.35$ \\
\hline
\end{tabular}

Litterfall production is a major process by which carbon and nitrogen are transferred from vegetation to the soil. The litterfall pattern in secondary mixed deciduous in tropical ecosystems is determined by various factors, including species composition, the successional stage in the development of the system and related microclimatic differences (Sundarapandian, Swamy 1999). Therefore, variations in the litterfall patterns between land use types, especially forest and agriculture, were expected in this study. 


\section{Litterfall fraction}

Leaves always represented the largest fraction in the secondary mixed deciduous forest (tab. 1). Mean litter fall production differed significantly between the wet and dry periods. Litterfall may be affected by physical factors such as the mechanical action of rainfall, the temperature and the wind or by the physical responses of the plants to environmental changes (Satiago, Mulkey 2005). This study found a seasonal pattern of litterfall production which increased in the dry period (October-April) and decreased in the wet period (May-September). Most litterfall studies in tropical forests have demonstrated a strong seasonality of leaf litterfall, with the dry season producing the peak litterfall (Wieder, Wright 1995). The pattern of litterfall in the current study was consistent with the seasonal patterns in vegetation. The leaves fraction of litterfall was highest (over $50 \%$ ) in secondary mixed deciduous forest.

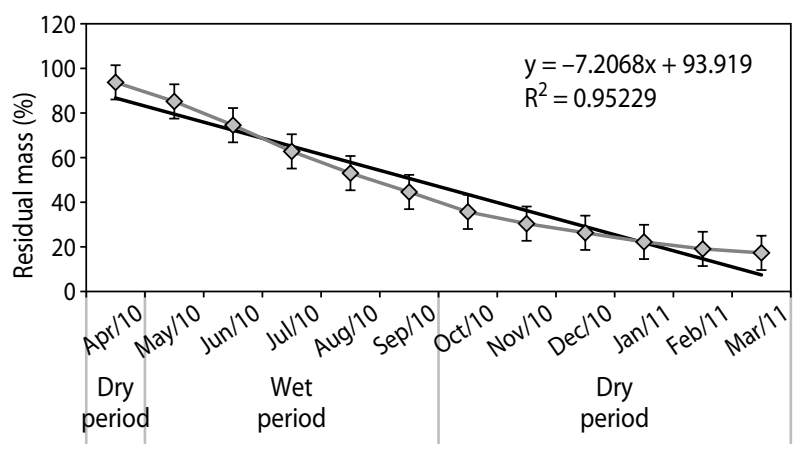

Fig. 2. Residual mass (\% of the initial) of secondary mixed deciduous forest (SMDF) from April 2010 to March 2011 and during the wet and dry periods

\section{Litterfall decomposition}

The decomposition of leaf litter under secondary mixed deciduous forest based on the results of the litter bag method was studied over about 12 months. The monthly decomposition coefficients $(k)$ in the secondary mixed deciduous forest from 0.02 to $0.59 /$ year and the average annual decomposition constant $(k)$ were $0.15 \pm 0.04$ /year (fig. 3) for the secondary mixed deciduous forest. As would be expected, the pattern for the coefficients was highest in the wet period (May-September) and lowest in the dry period (October-April) (fig. 4). The secondary mixed deciduous forest suggest the possible effect of land use on the levels of carbon and nitrogen in the litter released to the soil with regard to the carbon balance in each land use system. Different species types in a land use system have been reported to have different nutrient release patterns, which are related to the litter quality and seasonal environmental factors (Kavvadias et al. 2001).

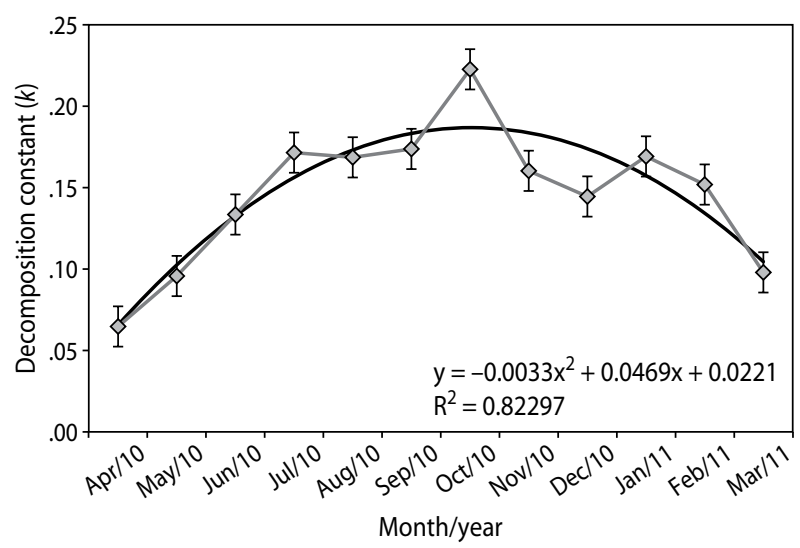

Fig. 3. Decomposition constant $(k)$ of secondary mixed deciduous forest (SMDF) from April 2010 to March 2011

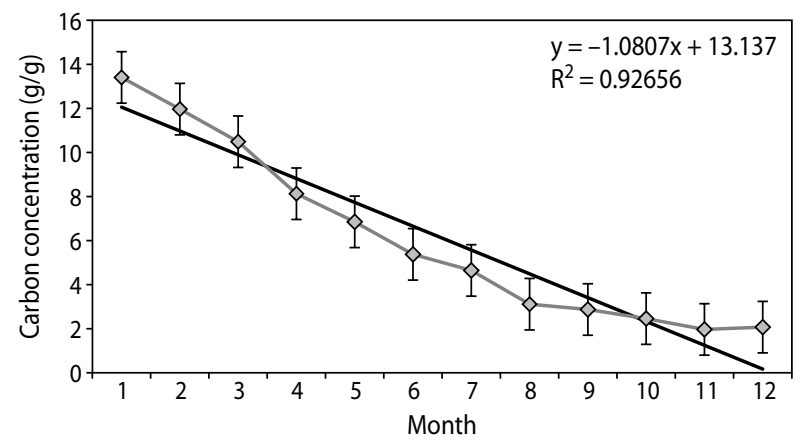

Fig. 4. Changes in carbon $(\mathrm{g} / \mathrm{g})$ over a decomposition time of 1 year under secondary mixed deciduous forest (SMDF). Vertical lines represent standard error from 12 replicate measurements

\section{Carbon and nitrogen return and release from litter}

Carbon and nitrogen returns from litterfall are of interest because they can help understand the nutrient uptake in a land use system. In this study, the carbon return of litterfall in the secondary mixed deciduous forest was $268.83 \mathrm{~g} / \mathrm{m}^{2} /$ year as shown in table 4 . The nitrogen return of litterfall was $5.308 \mathrm{~g} / \mathrm{m}^{2} /$ year as shown in table 5 . The nutrient release from decomposing litter is a key process governing the availability of nutrients in ecosystem Moore et al. 2006). The carbon and nitrogen return 
patterns increased in the dry period (October-April) and decreased in the wet period (May-September).

Tab. 4. Amount of Carbon returns ( $\mathrm{g} / \mathrm{m}^{2} /$ year) collected over 1 year under secondary mixed deciduous forest. The contribution of each fraction of litterfall to total litterfall production is also reported

\begin{tabular}{|c|c|c|c|c|c|c|}
\hline 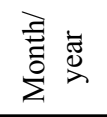 & 离 & $\underbrace{.00}_{1}$ & 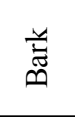 & 遂 & 㐫 & 吾 \\
\hline Apr/10 & 12.09 & 711 & 0.75 & 3.68 & 2.50 & 27.23 \\
\hline May10 & 5.79 & 7.51 & 0.67 & 1.07 & 1.07 & 17.19 \\
\hline Jun/10 & 4.30 & 3.02 & 0.10 & 0.49 & 0.32 & 8.82 \\
\hline $\mathrm{Jul} / 10$ & 3.66 & 2.22 & 0.11 & 0.51 & 0.47 & 7.52 \\
\hline Aug/10 & 5.05 & 5.04 & 0.11 & 0.50 & 0.22 & 12.08 \\
\hline Sep/10 & 7.76 & 3.07 & 0.00 & 1.51 & 0.02 & 15.36 \\
\hline Oct/10 & 6.37 & 8.09 & 0.16 & 1.11 & 0.00 & 27.21 \\
\hline Nov10 & 11.64 & 2.38 & 0.02 & 0.26 & 0.00 & 17.90 \\
\hline $\mathrm{Dec} / 10$ & 5.10 & 4.47 & 0.08 & 0.25 & 0.00 & 15.96 \\
\hline $\operatorname{Jan} / 11$ & 14.56 & 4.54 & 0.08 & 0.17 & 0.00 & 25.25 \\
\hline $\mathrm{Feb} / 11$ & 24.12 & 6.16 & 0.05 & 0.22 & 0.00 & 54.96 \\
\hline Mar/11 & 19.62 & 8.63 & 0.13 & 0.14 & 0.05 & 39.35 \\
\hline Total & 120.00 & 62.23 & 2.26 & 9.90 & 4.66 & 268.80 \\
\hline
\end{tabular}

Tab. 5. Amount of Nitrogen returns ( $\mathrm{g} / \mathrm{m}^{2} /$ year) collected over 1 year under secondary mixed deciduous forest. The contribution of each fraction of litterfall to total litterfall production is also reported

\begin{tabular}{|c|c|c|c|c|c|c|}
\hline $\begin{array}{l}\stackrel{\Xi}{\Xi} \bar{\Xi} \\
\stackrel{0}{\Sigma}\end{array}$ & 离 & $\underbrace{\infty}_{\vec{b}}$ & 产 & 它总 & 㐫 & 苞 \\
\hline Apr $/ 10$ & 231 & & & 0.111 & 0.106 & 0.722 \\
\hline May10 & 10 & & 0.010 & 0.036 & 0.053 & 0.507 \\
\hline & 0.141 & 0.073 & 0.002 & 0.008 & 0.014 & 0.238 \\
\hline $\mathrm{Jul} / 10$ & .127 & 0.062 & 0.002 & 0.014 & 0.021 & 0.227 \\
\hline Aug/10 & 0.187 & 0.122 & 0.003 & 0.016 & 0.010 & 0.339 \\
\hline Sep/10 & 0.257 & 0.065 & 0.003 & 0.046 & 0.001 & 0.371 \\
\hline Oct/10 & 0.201 & 0.163 & 0.005 & 0.039 & 0.019 & 0.427 \\
\hline Nov10 & 0.351 & 0.055 & 0.000 & 0.010 & 0.000 & 0.416 \\
\hline $\mathrm{Dec} / 10$ & 0.139 & 0.095 & 0.002 & 0.006 & 0.007 & 0.248 \\
\hline $\mathrm{Jan} / 11$ & 0.352 & 0.076 & 0.002 & 0.006 & 0.000 & 0.437 \\
\hline $\mathrm{Feb} / 11$ & 0.605 & 0.123 & 0.001 & 0.008 & 0.000 & 0.737 \\
\hline Mar/11 & 0.494 & 0.134 & 0.003 & 0.004 & 0.002 & 0.638 \\
\hline Total & 3.396 & 1.314 & 0.061 & 0.304 & 0.232 & 5.308 \\
\hline
\end{tabular}

Carbon and nitrogen loss in the decomposing litter continually decreased during the decomposition process from the initial levels, with a final relatively rapid release in the wet period (fig. 4) and (fig. 5). The dynamics of the carbon and nitrogen amounts of biochemical nutrients are ecologically important. Changes in the amounts of carbon and nitrogen directly influence the availability of nutrient to plant and soil organisms in a land use system (Liao et al. 2006). The high decomposition of leaf litter in the current study generally occurred during the wet season (May-September) because the temperature and moisture conditions during this period suited decomposition activity and frequent rain showers promoted leaching (Liao et al. 2006).

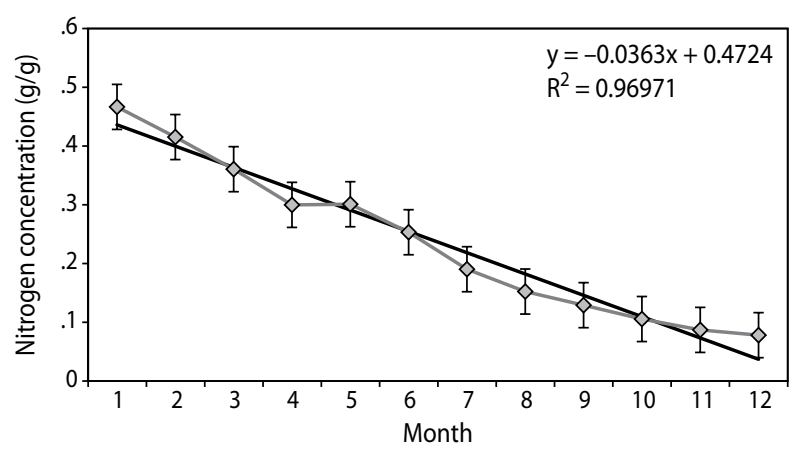

Fig. 5. Changes in nitrogen $(\mathrm{g} / \mathrm{g})$ over a decomposition time of 1 year under secondary mixed deciduous forest (SMDF). Vertical lines represent standard error from 12 replicate measurements

\section{Disscussion}

It is recognized that moisture in one of the important factors that control species composition of each forest, this results is also supported by Pongumpai (1976); (Glumphabutr et al. 2006). Number of species depends on soil moisture in the forest and it will increase as soil moisture content gradient increase from dry dipterocarp forest to mixed deciduous forest, dry evergreen forest, hill evergreen forest toward the moist evergreen forest respectively (Ogawa et al. 1965). Comparable litterfall rates in secondary forest have been reported to average $1,040 \pm 0.6 \mathrm{~g} / \mathrm{m}^{2} /$ year (Chazdon 2003) and observed aboveground inputs within a tropical forest have been reported to be between 880 and $1,000 \mathrm{~g} / \mathrm{m}^{2} /$ year (Vitousek 1984). 


\section{Conclusion}

The species composition of secondary mixed deciduous forest is low rich and diversity but that is high density. The comparison between secondary mixed deciduous forest after shifting cultivation at Thung Salaeng Luang National Park and other forest is tree density higher than other forest but number of species is similarity or lower. The dominant species of trees were Haldina cordifolia, Albizia odoratissima and Lagerstroemia duperreana. The IVI values of trees were 132.91, 17.78 and 14.22, respectively. Species diversity compared to other forests, The Fisher's, Shannon-Wiener's index and Simpson's index in these studies are found to be lower than other forests. The seasonal pattern of litterfall production which increased in the dry period (October-April) and decreased in the wet period (May-September). The pattern for the decomposition coefficients $(\mathrm{k})$ was highest in the wet period (May-September) and lowest in the dry period (October-April). The carbon and nitrogen return patterns increased in the dry period (OctoberApril) and decreased in the wet period (May-September). Carbon and nitrogen loss in the decomposing litter continually decreased during the decomposition process from the initial levels, with a final relatively rapid release in the wet period. Land use cover could impact on nutrient cycling in the land use especially the potential of each land use for balancing carbon for mitigating greenhouse gas effect in the local area. Therefore, any land use conversion should take into account the impact of local action on the global perspective.

\section{Acknowledgement}

The research was supported by a CHE-Ph.D-SWNEWU scholarship from the Commission on Higher Education, and by Uttaradit Rajabhat University. The Department of National Parks, Wildlife and Plant Conservation is thanked for giving permission to access and collect data from the study area.

\section{References}

Berg B. 2000. Litter decomposition and organic matter turn over in Northern forest soils. Forest Ecology and Management, 133, 13-22.

Boonyanuphap J., Sakurai K., Tanaka S. 2007. Soil nutrient status under upland farming practice in the Lower Northern Thailand. Tropics, 16 (3), 215-231.

Brown S., Lugo A.E. 1990.Tropical secondary forests. Journal of Tropical Ecology, 6, 1-32.

Chazdon R.L. 2003.Tropical forest recovery: legacies of human impact and natural disturbances. Perspective in Plant Evolution and Systematic, 6, 51-71.

Cuevas E., Brown S., Lugo A.E. 1991. Above-and below organic matter storage and production in a tropical pine plantation and a paired leaf productivity along a precipitation gradient in lowland Panama: patterns from leaf to ecosystem. Structure Function, 19 (3), 349-356.

Evans K.D., Marney E.I., Quashie-Sam J. 2010. Litterfall and litter nutrient dynamics under cocoa ecosystems in lowland humid Ghana. Plant and Soil, 330, 55-64.

Finegan B.1996. Pattern and process in neotropical secondary rain forests: the first 100 years of succession. Trends in Ecology and Evolution, 11, 119-124.

Fugushima M., Kanzaki M., Hara M., Ohkubu T., Preechapanya P., Choochareon C. 2008. Secondary forest succession after the cessation of swidden cultivation in the montane forest area in Northern. Forest Ecology and Management, 255, 1994-2006.

Glumphabutr P., Kaitpraneet S., Wachrinrat J. 2006. Structural Characteristic of Natural Evergreen Forests in Eastern Region of Thailand. Thai Journal of Forestry, 25, 92-111.

Guariguata M.R., Ostertag R. 2001. Neotropical secondary forest succession: changes in structural and functional characteristics. Forest Ecology and Management, 148, 185-206.

Kanjunt C., Oberhauser U. 1994. Successional forest development in abandoned swidden plots of Hmong, Karen, and Lisu ethnic groups. NAMSA Research Paper. Sam Muen-Highland Development Project, Thailand.

Kanzaki M., Kawaguchi H., Sahunalu P., Dhanmanonda P., Tanpibal V., Puriyakorn B., Muangnil K., Preechapanya P., Yoda K. 1991. Climate, topography, and initial vegetation of experiment sites with 
reference to the dynamics of natural forest. In: Improvement of biological productivity of tropical wastelands in Thailand (eds.: K. Yoda, P. Sahunalu), Department of Biology, Osaka City University, Osaka, Japan, 23-47.

Kartawinata K., Riswan S., Soedjito H. 1980. The Floristic change after disturbances in lowland dipterocarp forest in East Kalimantan, Indonesia. Tropical Ecology and Development. Proceeding of the $5^{\text {th }}$ International Symposium of Tropical Ecology, 47-54.

Kellman M.C. 1969. Some environmental components of shifting cultivation in upland Mindanao. Journal of Tropical Geography, 28, 40-56.

Khopai A. 2006. The Study of Plant Community in Khao Kaset Forest Area and Tree Species Diversity in Kasetsart Si Racha Campus. Thai Journal of Forestry, 25, 1-18.

Kochummen K.M., Ng F.S.P. 1977. Natural plant succession after farming in Kepong. Malayan Forester, 40, 61-78.

Kyuma K., Pairintra C. 1983. Shifting cultivation: An Experiment at Nam Phrom, Northeast Thailand, and Its Implications for Upland Farming in the Monsoon Tropics. Kyoto University, Faculty of Agriculture, Kyoto.

Liao J.H., Wang H.H., Tsai C.C., Hseu Z.Y. 2006. Litter production, decomposition and nutrient return of uplifted coral reef tropical forest. Forest Ecology and Management, 235, 174-185.

Li Y., Xu M., Zou X., Shi P., Zhang Y. 2005. Comparing soil organic carbon dynamics in plantation and secondary forest in wet tropics in Puerto Rico. Global Change Biology, 11, 239-248.

Lugo A.E. 1992. Comparison of tropical tree plantations and with secondary forests of similar age. Ecological Monographs, 62, 1-41.

Martius C., Hubert H., Marcos V.B.G., Jörg M., Hanagarth W. 2004. Litterfall, litter stocks and decomposition rates in rainforest and agroforestry sites in central Amazonia. Nutrient Cycling in Agroecosystems, 68, 137-154.

Moore T.R., Trofymow J.A., Prescott C.E., Fyles J., Titus B.D. 2006. Patterns of carbon, nitrogen and phosphorus dynamics in decomposing foliar litter in Canadian forests. Ecosystem, 9, 46-62.
Nukool T. 2002. Structural Characteristics of Three Forest Types at Khun Korn Waterfall Forest Park, Changwat Chiang Rai. M.S. Thesis, Kasetsart University, Bangkok, Thailand.

Ogawa H., Yoda K., Ogino K., Kira T. 1965. Comparative ecological studies on three main types of forest vegetation in Thailand II. Plant Biomass. Nature and Life in Southeast Asia, 4, 49-80.

Olson J.S. 1963. Energy storage and the balance of producers and decomposers in ecological systems. Ecology, 44, 322-331.

Ostertag R., Marı́n-Spiotta E., Silver L.S., Schulten J. 2008. Litterfall and Decomposition in Relation to Soil Carbon Pools Along a Secondary Forest Chronosequence in Puerto Rico. Ecosystem, 11, 701-714.

Pongumpai S. 1976. Dendrology. Forest Biology Department, Faculty of Forestry, Kasetsart University, Bangkok, Thailand

Ranger J., Gerand F., Lindermann M., Gelhaye D., Gelhaye L. 2003. Dynamics of litterfall in a chonosequence of Douglas-fir (Pseudotsuga menziesii Franco) lands in the Beaujolais mounts (France). Annals of Forest Science, 60, 475-488.

Royal Forest Department. 1962. Type of forest of Thailand. Ministry of Agriculture, Bangkok, Thailand.

Satiago L.S., Mulkey S.S. 2005. Leaf productivity along a precipitation gradient in lowland Panama: patterns from leaf to ecosystem. Structure Function, 19 (3), 349-356.

Srikanha P., Gajaseni J. 2000. Structure, compositions and species diversity in deciduous forest ecosystem in Huai Kha Khaeng Wildlife Sanctuary, Thailand. In research reports on biodiversity in Thailand, Biodiversity Research and Training Program (BRT), 11-14 ${ }^{\text {th }}$ October 2000, 710-714.

Suksomut P. 1987. Community dynamics of hill evergreen forest at Huay Nam Dang Watershed Station, Chiang Mai Province. M.S. Thesis, Kasetsart University. Bangkok, Thailand.

Sundarapandian S.M., Swamy P.S. 1999. Litter production and leaf-litter decomposition of select tree species in tropical forest at Kodayar in the Western Ghats, India. Forest Ecology and Management, 123, 231-244. 
Symingyon C.F. 1993. The Study of secondary growth on rain forest sites in Malaya. Malayan Forester, 2, 107-117.

Triadiati T., Tjitrosemito S., Guhardja E., Sudarsono I., Qayim I., Leuschner C. 2011. Litterfall Production and Leaf- Litter Decomposition at Natural Forest and Cacao Agroforestry in Sulawesi, Indonesia. Asian Journal of Biological Sciences, 4 (3), 221-234.

Vitousek P.M. 1984. Litterfall, nutrient cycling, and nutrient limitation in tropical forest. Ecology, 65, 285-298.

Wang Q., Wang S., Huang Y. 2008. Comparison of litterfall, Litter decomposition and nutrient return in monoculture Cunninghamia lanceolata and mixed stand in Southern China. Forest Ecology and Management, 255, 1210-1218.

Wieder R.K., Wright S.J. 1995. Tropical forest litter dynamics and dry season irrigation on Barro Colorado Island, Panama. Ecology, 76 (6), 1971-1979.

Wyatt-Smith J. 1955. Changes in Composition in Early Natural. Plant Succession, 18, 44-49.

Yang Y.S., Guo J.F., Chen G.S., He Z.M., Xie J.S. 2003. Effect of slash burning on nutrient removal and soil fertility in Chinese farm and evergreen broadleaved forests of midsubtropical China. Pedosphere, 13, $87-96$ 